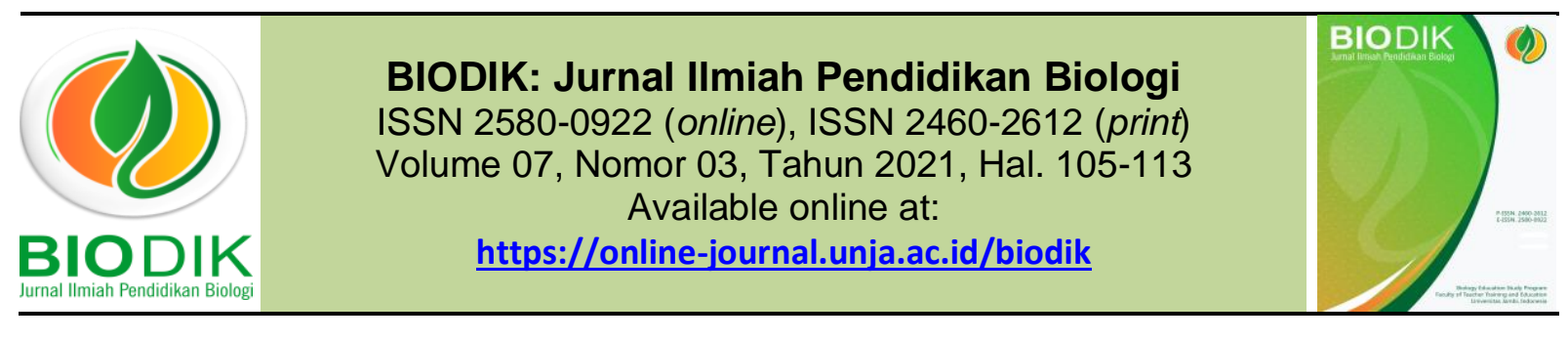

Research Article

OPEN ACCESS

\title{
Hubungan Antara High Order Thinking Skills dan Kemampuan Literasi Sains Mahasiswa Pendidikan Biologi
}

\section{(The Relationship Between High Order Thinking Skills and Science Literacy Abilities of Biology Education Students)}

\author{
Rahmatia Thahir*, Nurul Magfirah, Anisa
}

Program Studi Pendidikan Biologi, Universitas Muhammadiyah Makassar

Jalan Sultan Alauddin no. 259 Makassar, Sulawesi Selatan- Indonesia 90221

*Corresponding author: rahmatiah.thahir@unismuh.ac.id

\begin{tabular}{|c|c|}
\hline Informasi Artikel & ABSTRACT \\
\hline $\begin{array}{l}\text { Submit: } 21-06-2021 \\
\text { Diterima: } 28-08-2021 \\
\text { Dipublikasikan: } 28-09-2021\end{array}$ & $\begin{array}{l}\text { Higher Order Thinking Skills can develop the ability to investigate problems, ask } \\
\text { questions, pose challenging answers and discovernew information. Higher order } \\
\text { thinking skills are one of the factors that affect scientific literacy skills. Literacy } \\
\text { skills are not enough just to be able to read, more than that, students are } \\
\text { expected to have the ability to reason and competence, be active, creative, and } \\
\text { critical of what they know. The purpose of this study was to analyze the } \\
\text { relationship between higher order thinking skills and scientific literacy skills of } \\
\text { Biology Education students, University of Muhammadiyah Makassar. This } \\
\text { research includes correlational descriptive research which is carried out in the } \\
\text { even semester of the 2020-2021 academic year. The instrument in this study } \\
\text { was in the form of student learning outcomes tests. Then from student learning } \\
\text { outcomes, a score will be given based on the ability to complete the HOTS test } \\
\text { questions while the scientific literacy ability is assessed using a scoring rubric. } \\
\text { there is a positive relationship between higher order thinking skills and scientific } \\
\text { literacy skills of biology education students at the University of Muhammadiyah } \\
\text { Makassar with a correlation value of 0.370. The value of learning outcomes with } \\
\text { the average categorization of high order thinking skills is } 56.7 \text { and the average } \\
\text { scientific literacy ability is } 66.7 \text {. } \\
\text { Keywords: HOTs, scientific literacy skills }\end{array}$ \\
\hline Penerbit & ABSTRAK \\
\hline $\begin{array}{l}\text { Program Studi Pendidikan Biologi } \\
\text { FKIP Universitas Jambi, } \\
\text { Jambi- Indonesia }\end{array}$ & $\begin{array}{l}\text { Higher Order Thinking Skils dapat menumbuhkembangkan kemampuan untuk } \\
\text { menyelidiki masalah, mengajukan pertanyaan, mengajukan jawaban yang } \\
\text { menantang dan menemukan informasi baru. Kemampuan berpikir tingkat tinggi } \\
\text { merupakan salah satu faktor yang mempengaruhi kemampuan literasi sains. } \\
\text { Kemampuan literasi tidak cukup dengan bisa membaca saja, lebih daripada itu } \\
\text { mahasiswa diharapkan memiliki kemampuan bernalar dan kompetensi, aktif, } \\
\text { kreatif, serta kritis terhadap apa yang diketahuinya. Tujuan dari penelitian ini } \\
\text { adalah untuk menganalisis hubungan antara higher order thinking skills dan } \\
\text { kemampuan literasi sains mahasiswa Pendidikan Biologi Universitas } \\
\text { Muhammadiyah Makassar. Penelitian ini termasuk penelitian deskriptif } \\
\text { korelasional yang dilaksanakan pada semester genap tahun akademik 2020- } \\
\text { 2021. Instrument dalam penelitian ini berupa tes hasil belajar mahasiswa. } \\
\text { Kemudian dari hasil belajar mahasiswa akan diberikan penskoran berdasarkan } \\
\text { kemampuan menyelesaikan soal tes HOTS sedangkan kemampuan literasi } \\
\text { sains dinilai dengan menggunakan rubrik penskoran. terdapat hubungan yang } \\
\text { positif antara higher order thinking skills dan kemampuan literasi sains } \\
\text { mahasiswa pendidikan biologi Universitas Muhammadiyah Makassar dengan }\end{array}$ \\
\hline
\end{tabular}


nilai korelasi sebesar 0,370 . Nilai hasil belajar dengan pengkategorian rata-rata higher order thinking skills sebesar 56,7 dan rata-rata kemampuan literasi sains sebesar 66,7.

Kata kunci: HOTs, Kemampuan Literasi sains

This BIODIK : Jurnal IImiah Pendidikan Biologi is licensed under a CC BY-NC-SA (Creative Commons Attribution-ShareAlike 4.0 International License)

\section{PENDAHULUAN}

Perubahan global dirasakan semakin cepat memasuki abad 21. Perubahan tersebut berdampak pada segala sektor pembangunan bangsa termasuk bidang Pendidikan. Pendidikan merupakan tolak ukur dalam menentukan kemajuan suatu bangsa. Pendidikan saat ini mendorong generasi muda untuk dapat mengembangkan potensi dirinya dengan terus berinovasi dan berkarya sehingga bisa tetap bertahan dalam menghadapi persaingan global. Pendidikan mempersiapkan mahasiswa berkualitas yang memiliki kesadaran sains, nilai, kerampilandan sikap (Thahir et al., 2021). Salah satu hal yang harus dilaksanakan adalah mengembangkan potensi melalui bidang Pendidikan sains. Sains diperlukan dalam kehidupan sehari-hari untuk memenuhi kebutuhan manusia melalui pemecahan masalah-masalah yang dapat diidentifikasi. Segala permasalahan tersebut dapat dipecahkan jika masyarakat mempunyai literasi sains. Upaya peningkatan literasi sains di bidang Pendidikan mulai dilakukan pada jenjang Sekolah Menengah oleh pemerintah dengan cara mengimplementasikan kurikulum 2013. Pola pembelajaran kurikulum 2013 menggunakan pendekatan saintifik yang menekankan kepada higher order thinking skills (Susiati et al., 2018).

Literasi sains merupakan kemampuan seseorang menggunakan konsep sains untuk mengaplikasikannya dalam kehidupan, menjelaskan fenomena ilmiah serta menggambarkan fenomena tersebut berdasarkan bukti-bukti ilmiah. Kemampuan literasi tidak hanya sekedar membaca dan menulis, namun melibatkan keterampilan berpikir yang membuat mereka menjadi generasi literat dalam belajar termasuk dalam pembelajaran sains. Kemampuan berliterasi peserta didik yaitu mahasiswa berkaitan erat dengan tuntutan keterampilan membaca yang berujung pada kemampuan memahami informasi secara analisis, kritis, dan reflektif (Septiani et al., 2020). Mahasiswa memiliki kemampuan berpikir kreatif dan memecahkan masalah, kemampuan berkomunikasi dan berkolaborasi, dan kemampuan untuk berkreativitas serta berinovasi. Selain itu harus juga memiliki kemampuan menguasai media, informasi dan teknologi. Sementara itu dalam kehidupan karir peserta didik harus memiliki kemampuan secara fleksibel dan adaptif, inisiatif dan mandiri, mampu berinteraksi sosial, produktif dan akuntabel, serta memiliki jiwa kepemimpinan dan bertanggung jawab.

Kemampuan berpikir tingkat tinggi merupakan keterampilan berpikir kritis, salah satunya adalah kemampuan dalam membuat keputusan yang dapat dipercaya dan bertanggung jawab. Kemampuan berpikir tingkat tinggi dapat menumbuhkembangkan kemampuan untuk menyelidiki masalah, mengajukan pertanyaan, mengajukan jawaban yang menantang dan menemukan informasi baru. Kemampuan berpikir tingkat tinggi merupakan salah satu faktor yang mempengaruhi kemampuan literasi sains. Hal ini sesuai dengan pernyataan Abruscato dalam (Yuriza et al., 2018) yang menyebutkan tujuan utama Pendidikan sains adalah membentuk manusia yang memiliki kreativitas, berpikir ktitis, menjadi warga negara yang baik, dan menyadari karier yang luas, oleh karena itu, pembejaran sains saat ini mengarahkan pebelajar menjadi literat terhadap sains, sehingga berimplikasi terhadap kemampuan berpikir tingkat tinggi dan pemecahan masalah. Agar mereka dapat memahami dan kritis, tidak hanya 
mengingat informasi tetapi juga pada pencapaian tujuan pembelajaran dalam arti luas, yaitu kepribadian yang paham sains.

Berdasarkan hasil survei Trends in Internasional Mathematics and Science Study (TIMSS) tahun 2011, menempatkan Indonesia pada posisi 35 pada bagian sains dari 49 negara peserta. Literasi sains generasi siswa di Indonesia tergolong dalam kategori yang rendah dikarenakan proses pembelajaran yang belum maksimal untuk meningkatkan kemampuan literasi sains (Fitriani et al., 2018). Hasil observasi yang dilakukan pada hari senin, 12 April 2021 melalui wawancara kepada beberapa mahasiswa Program Studi Pendidikan Biologi Fakultas Keguruan dan IImu Pendidikan Universitas Muhammadiyah Makassar semester genap tahun akademik 2020-2021, dalam wawancara tersebut berisikan pertanyaanpertanyaan yang mengarah pada gambaran awal pemahaman mahasiswa tentang kemampuan berpikir tingkat tinggi dan kemampuan literasi sains. Pertanyaan yang diberikan berkaitan tentang adakah hubungan antara kemampuan berpikir tingkat tinggi dan kemampuan literasi sains. Dari hasil wawancara tersebut, beberapa mahasiswa mengemukakan bahwa kemampuan berpikir tingkat tinggi memiliki kaitan yang erat dengan kemampuan literasi sains, akan tetapi lebih lanjut mahasiswa tersebut tidak bisa menjelaskan lebih terperinci tentang hubungan kemampuan berpikit tingkat tinggi dengan kemampuan literasi sains.

Mengingat urgensi penelitian mengenai hubungan antara kemampuan berpikir tingkat tinggi dan kemampuan literasi sains ini, ada beberapa penelitian relevan pada beberapa tahun terakhir. Hasil penelitian yang dilakukan oleh (Bagasta et al., 2018) menunjukkan bahwa kemampuan literasi sains secara umum peserta didik mempunyai kemampuan literasi sains yang rendah. Selain itu, penelitian yang dilakukan oleh (Andriani et al., 2018) menunjukkan bahwa kemampuan literasi sains siswa keseluruhan ditinjau dari level soal dan kompetensi proses diperoleh hasil yang masih rendah. Berdasarkan uraian hal tersebut, sejauh ini belum banyak informasi yang memberikan data tentang keterkaitan antara kemampuan berpikir tingkat tinggi dan kemampuan literasi sains pada pembelajaran biologi khususnya mahasiswa Pendidikan Biologi Universitas Muhammadiyah Makassar. Oleh karena itu penelitian ini bertujuan untuk menganalisis hubungan antara higher order thinking skills dan kemampuan literasi sains mahasiswa Pendidikan Biologi Universitas Muhammadiyah Makassar.

\section{METODE PENELITIAN}

Jenis Penelitian ini merupakan penelitian deskriptif kuantitatif. Penelitian deskriptif kuantitatif adalah penelitian yang dilakukan untuk meneliti variabel yang telah terjadi tanpa perlu memberikan perlakukan variabel yang diteliti. Penelitian deskriptif korelasional dengan teknik analisis korelasional yang digunakan yaitu perason product moment atau analisis regresi sederhana. Penelitian ini dilaksanakan pada Program Studi Pendidikan Biologi FKIP Universitas Muhammadiyah Makassar pada semester genap 2020-2021. Penelitian ini menganalisis hubungan antara dua variabel yaitu higher Order Thinking Skills $(X)$ sebagai variabel bebas dan kemampuan literasi sains $(Y)$ sebagai variabel terikat. Adapun desain dari penelitian ini digambarkan pada gambar 1.
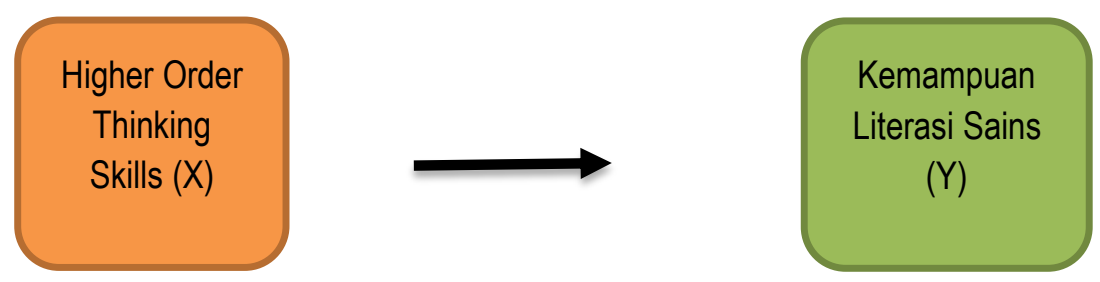

Gambar 1. Desain Penelitian 
Populasi pada penelitian ini adalah mahasiswa semester VI angkatan 2018. Total jumlah keseluruhan populasi adalah 52 mahasiswa. Teknik pengambilan sampel adalah saturation sampling. Karena populasi tidak mencapai 100 maka semua populasi akan menjadi sampel dalam penelitian ini. Instrumen dalam penelitian ini adalah soal tes hasil belajar mahasiswa pada mata kuliah Biologi Laut dalam bentuk tes uraian/ essay sebanyak 10 nomor. Tes tersebut dibuat berdasarkan tingkatan kognitif dalam taksonomi Bloom yaitu C4 (menganalisis), C5 (Mengevaluasi), dan C6 (Mencipta). Teknik pengumpulan data dalam penelitian ini menggunakan instrument tes berupa soal uraian yang diberikan pada mahasiswa pada ujian akhir semester. Data diperoleh dari hasil tes mahasiswa akan dinilai kemampuan dalam mengerjakan soal HOTS dan kemampuan literasi sains.

Data dianalisis menggunakan analisis statistik deskriptif dan analisis statistik inferensial. Data yang akan dianalisis secara deskriptif adalah data Higher Order Thinking Skills dan kemampuan literasi sains dari nilai hasil tes mahasiswa. Skor Higher Order Thinking Skills mahasiswa adalah jumlah skor yang diperoleh pada saat menyelesaikan soal tes Higher Order Thinking Skills. Sedangkan skor kemampuan literasi sains mahasiswa dinilai menggunakan rubrik penskoran. Data hasil tes mahasiswa dianalisis untuk menentukan kategori tingkat Higher Order Thinking Skills mahasiswa pada tabel 1.

Tabel 1. Kategori Penilaian Higher Order Thinking Skills

\begin{tabular}{cc}
\hline Skor & Kategori \\
\hline $85.00-100,00$ & Sangat Tinggi \\
\hline $70,00-84,99$ & Tinggi \\
\hline $55,00-69,99$ & Cukup \\
\hline $40,00-54,99$ & Rendah \\
\hline $0-39,99$ & Sangat Rendah \\
\hline
\end{tabular}

Sumber: Ridwan dalam (Intan et al., 2020)

Sedangkan data hasil penilaian kemampuan literasi sains yang diperoleh dikategorikan berdasarkan tabel 2 .

Tabel 2 Kategori penilaian kemampuan literasi sains

\begin{tabular}{cc}
\hline Skor & Kategori \\
\hline $86-100$ & Sangat Tinggi \\
\hline $76-85$ & Tinggi \\
\hline $60-75$ & Sedang \\
\hline $55-59$ & Rendah \\
\hline$\leq 54$ & Sangat Rendah \\
\hline
\end{tabular}

Sumber: (Purwanto, 2013)

Selanjutnya data dianalisis statistik inferensial digunakan untuk menguji kebenaran hipotesis yang diajukan, yakni digunakan analisis korelasi Pearson Product Moment atau regresi sederhana dengan bantuan SPSS 25. Adapun pedoman interpretasi nilai koefisien korelasi (nilai r) dapat dilihat pada tabel 3 .

Tabel 3 Pedoman interpretasi koefisien korelasi

\begin{tabular}{|c|c|}
\hline Interval Koefisien & Tingkat Hubungan \\
\hline $0,80-1,000$ & Sangat Kuat \\
\hline $0,60-0,799$ & Kuat \\
\hline $0,40-0,599$ & Cukup Kuat \\
\hline $0,20-0,399$ & Lemah \\
\hline $0,00-0,199$ & Sangat Lemah \\
\hline
\end{tabular}

Sumber: (Sugiyono, 2017) 
Sebelumnya dilakukan uji hipotesis terlebih dahulu dilakukan uji Normalitas dan Linearitas. Uji Normalitas dilakukan untuk mengetahui distribusi normal data yang diperoleh dengan menggunakan analisis Kolmogrov Smirnov. Sedangkan uji linearitas dimaksudkan untuk mengetahui linear tidaknya hubungan masing-masing variabel penelitian dengan menggunakan analisis test for linearity pada SPSS 25. Adapun hipotesis dari penelitian ini adalah ada hubungan yang kuat antara Higher Order Thinking Skills dan Kemampuan Literasi Sains Mahasiswa Pendidikan Biologi Universitas Muhammadiyah Makassar.

\section{HASIL PENELITIAN DAN PEMBAHASAN}

Adapun hasil uji analisis statistik deskriptif dari hasil kegiatan penelitian digunakan nilai rata-rata pada penilaian Higher order thinking skills dan kemampuan literasi sains mahasiswa Angkatan 2018 pendidikan biologi Universitas Muhammadiyah Makassar disajikan pada tabel dibawah ini.

Tabel 4. Hasil pengkategorian nilai rata-rata higher order thinking skills

\begin{tabular}{ccc}
\hline Skor & Kategori & Rata-rata \\
\hline $55,00-69,99$ & Cukup & 56,7 \\
\hline
\end{tabular}

Berdasarkan tabel 4 diatas menunjukkan bahwa ketercapaian hasil belajar mahasiswa pendidikan biologi angkatan 2018 pada mata kuliah biologi laut memiliki nilai rata-rata higher order thinking skills sebesar 56,7 yang berada pada kategori cukup dengan rentang skor 55,00-69,99. Hal ini disebabkan karena mahasiswa masih mengalami kesulitan dalam membuat kalimat yang tepat dan masih bingung dalam memberikan alasan atau solusi dalam pemecahan masalah pada saat mengerjakan soal.

Tabel 5. Hasil pengkategorian nilai rata-rata kemampuan literasi sains

\begin{tabular}{ccc}
\hline Skor & Kategori & Rata-rata \\
\hline $60-75$ & Sedang & 66,7 \\
\hline
\end{tabular}

Berdasarkan tabel 5 diatas menunjukkan bahwa ketercapaian hasil belajar mahasiswa Pendidikan biologi Angkatan 2018 pada mata kuliah biologi laut memiliki nilai rata-rata kemampuan literasi sains sebesar 66,7 yang berarti berada pada kategori sedang dengan rentang skor 60-75. Hal ini disebabkan karena kekmampuan literasi sains yang dimiliki mahasiswa kurang mampu ditingkatkan dalam waktu yang singkat sehingga membutuhkan waktu untuk melatih diri, dan membantu mahasiswa untuk suka membaca isu-isu ilmiah dan mempelajari fenomena alam yang terjadi disekitarnya. Ketika mahasiswa memilki HOTs kategori cukup dan kemampuan literasi sains kategori sedang, maka hubungan keduanya adalah mahasiswa belum mampu secara baik menerima dan mengelolah konsep/ materi yang di berikan, serta belum mampu memahami dan mengaplikasikan cara berpikir kirits, kreatif, dan pemecahan masalah dalam HOTs sehingga berdampak pula pada kemampuan menyelesaikan permasalahan sains yang diberikan.

Dari hasil analisis tersebut terlihat bahwa kemampuan berpikir tingkat tinggi atau higher order thinking skills mahasiswa mempunyai hubungan dengan kemampuan literasi sains karena kedua penilaian tersebut berada pada level ke 3 yaitu cukup dan sedang pada pengkategoriannya. Mahasiswa belum mampu menyelesaikan masalah dalam soal yang diberikan secara tepat, namun sudah mampu memberikan alasan. Tidak dapat dipungkiri bahwa hasil tersebut karena tidak terbiasanya mahasiswa dalam mengerjakan soal tipe HOTs dan masih kurang dalam membaca dan menganalisis isu-isu ilmiah terkait dengan biologi laut sehingga tidak mampu mencapai kategori tinggi. Maka dari itu perlu 
pembiasaan melakukan proses literasi dengan menggali dan menambah pengetahuan mereka dalam proses belajar. Kategori yang diperoleh mahasiswa walaupun masih berada pada ketegori cukup dan sedang telah memberikan gambaran bahwa mereka sudah cukup memahami akan situasi yang dialami selama melakukan kegiatan pembelajaran sehingga kemampuan higher order thinking skills digunakan apabila seseorang menerima informasi baru dan menyimpannya untuk kemudian digunakan kembali pada saat keperluan pemberian solusi atas masalah nersadarkan situasi. Hal ini sesuai dengan hasil penelitian (Ahmad et al., 2020) bahwa higher order thinking skills merupakan kemampuan untuk menghubungkan, memanipulasi, dan mengubah pengetahuan serta pengalaman yang sudah dimiliki secara kritis dalam menentukan keputusan untuk menyelesaikan masalah pada situasi baru. Demikian pulan menurut (Mustapa, 2014) bahwa pelajar yang memiliki keterampilan berpikir tingkat tinggi atau higher order thinking skills (HOTs) mampu membedakan antara fakta dan opini, mengidentifikasi informasi yang relevan, memecahkan masalah, dan mampu menyimpulkan informasi yang telah dianalisisnya.

Pembiasaan dalam pemberian soal Latihan dan pembelajaran dengan HOTs akan menjadikan mahasiswa menjadi terbiasa berpikir tingkat tinggi dan kritis dalam menyelesaikan permasalahan dan memberikan solusi yang diharapkan. Salah satu penerapan untuk menumbuhkan kemampuan berpikir tingkat tinggi yaitu dengan melakukan tes berupa soal-soal HOTs yang diberikan kepada siswa dengan tujuan untuk mengetahui seberapa besar kemampuan mereka dalam menyelesaiakn persoalan serta memahami soal-soal yang diberikan (Intan et al., 2020). HOTs mampu mengembangkan daya kreatif mahasiswa dengan melalui permasalahan-permasahan yang terjadi di lingkungan khususnya biologi laut Indonesia. Mahasiswa diajak untuk berpikir tingkat tinggi dalam menjawab dan memberikan solusi atas pencemaran lingkungan laut, kerusakan terumbu karang, dan pentingnya menanam mangrove. Sehingga mahasiswa dituntun untuk memperbanyak membaca literatur-literatur yang terkait dengan hal tersebut hal ini dapat meningkatkan kemampuan literasi sains mahasiswa. Mahasiswa aktif dalam mencari dan memerikan solusi atas permasalahan yang diberikan. Hal ini sesuai dengan penelitian yang telah dilakukan (Ahmad et al., 2020) yaitu dengan mengaplikasikan HOTs dalam pembelajaran memudahkan proses pembelajaran dan membuat siswa lebih aktif dan tidak terpaku pada metode cermaah saja. Oleh sebab itu HOTs menjadi solusi pembelajaran yang diminta dalam kegiatan merdeka belajar yang saat ini pembelajaran dilaksanakan secara daring.

Ketika mahasiswa telah memiliki kemampuan berpikir tingkat tinggi maka mahasiswa tersebut sudah memiliki pemikiran yang logis, kritis, dan mampu menalar suatu kejadian yang terjadi dalam kehidupan sehari-hari. HOTs membantu mahasiswa dalam pembelajaran karena mahasiswa akan diajar berpikir menemukan suatu ide atau pemikiran, mampu berargumen dengan baik, mampu memecahkan masalah, mampu berhipotesis, dan memahami seuatu hal kompleks sehingga terlihat bahwa mereka sedang bernalar (Wibawa \& Agustina, 2019). HOTs merupakan kemampuan berpikir yang tidak hanya mengujikan aspek ingatan dan hapalan saja, tetapi juga mengujikan sampai pada aspek analisis, sintesis, dan ebaluasi (Fitriani et al., 2018). Begitu pula dengan kemmapuan literasi sains yang dimiliki mahasiswa, mereka akan mempunyai pengetahuan ilmiah secara individual untuk menjelaskan fenomena ilmiah, kemampuan inkuiri, terbentuk lingkungan intektual, rasa keingintahuan tentang isu dan ide terkait sains (Asyhari \& Hartati, 2015).

Hasil uji analisis statistik inferensial menunjukkan bahwa terdapat hubungan yang positif antara higher order thinking skills dan kemampuan literasi sains mahasiswa pendidikan biologi Universitas Muhamamdiyah Makassar. Dimana higher order thinking skills sebagai variabel $(\mathrm{X})$ dan kemampuan 
literasi sains sebagai variabel $(\mathrm{Y})$ dengan menggunakan analisis korelasi Pearson Product Moment disajikan pada tabel dibawah ini.

Tabel 6. Hasil hasil analisis korelasi

\begin{tabular}{ccc}
\hline Interval Koefisien & Tingkat Hubungan & Koefisien Korelasi \\
\hline $0,20-0,399$ & Lemah & 0,370 \\
\hline
\end{tabular}

Berdasarkan tabel 6 menunjukkan bahwa nilai koefisien kolerasi sebesar 0,370 maka terdapat dapat korelasi atau hubungan antara higher order thinking skills dengan kemampuan literasi sains berbentuk hubungan yang positif namun tingkat korelasi lemah. Walaupun memiliki tingkat korelasi yang lemah namun memiliki pola hubungan positif yang serarah atau se level jika dilihat dari pengkategorian nilai higher order thinking skills dan nilai kemampuan literasi sains yang dimiliki mahasiswa. Artinya bahwa jika semakin tinggi nilai higher order thinking skills mahasiswa, maka semakin tinggi juga nilai literasi sains mahasiswa. Hal ini sejalan dengan penelitian yang telah dilakukan oleh (Rahayuni, 2016) yang menyatakan bahwa keterampilan berpikir kritis berbanding lurus dengan kemampuan literasi sains. Berdasarkan pernyataan dapat dijelaskan bahwa berpikir kritis atau berpikir tingkat tinggi merupakan salah satu faktor yang bersifat kognitif yang mempengaruhi kemampuan literasi sains. Jika mahasiswa memiliki higher order thinking skills dengan terus menambah rasa penasarannya akan suatu permasalahan, maka masiswa tersebut menjawab rasa penasarannya dengan membaca dan memahami berbagai sumber referensi atau literatur sampai memperoleh solusinya hal ini pula sudah menambah kemampuan literasi sainsnya.

Literasi sains secara langsung berkorelasi dengan membangun generasi baru yang memiliki pemikiran san sikap ilmiah, mampu mengkomunikasikan atau mendiskusikan ilmu dan hasil penelitian kepada masyarakat (Yuliati, 2017). Mahasiswa yang telah memiliki kemampuan literasi sains maka masiswa tersebut melihat dan menterjemahkan segala sesuatu secara ilmiah, memutuskan segala sesuatu dengan proses dan penilaian sains walaupun masalah tersebut berhubungan dengan kehidupan sehari-hari ataupun dengan olang lain, serta persoalan lingkungan hidup. Salah satu hal yang paling dianggap berpengaruh dalam dunia Pendidikan adalah tingkat kemampuan dan minat membaca siswa. Yang saat ini semakin berkurang. Artinya dalam dunia Pendidikan diperlukan suatu Gerakan. Gerakan yang dimkasud adalah gerkakan literasi dengan memanfaatkan teknologi informasi dan komunikasi cukup berkontribusi terhadap kemampuan berpikir kritis (Musalina et al., 2019).

Meski saat ini, di saat semua bisa menggunakan teknologi dalam pembelajaran pun bisa berlangsung hanya menggunakan $\mathrm{Hp}$ atau gadget saja. Tentu hal ini akan menjadi tantangan dalam dunia Pendidikan khusus dosen atau guru sebagai pendidik. Terlalu banyak godaan mahasiswa saat belajar, perhatian mereka terbagi dengan tontonan yang mereka anggap menarik dan menyenangkan. Ini yang menjadi salah satu penyebab mahasiswa kurang berkonsentrasi saat belajar. Namun kita sebagai pendidik harus selalu memberikan mereka motivasi untuk belajar dan mengarahkan pada pemikiran yang positif agar prestasi belajar mahasiswa lebih baik lagi dari sebelumnya. Karena prestasi mahasiswa selama perkuliahan dipengaruhi oleh faktor internal dan eksternal. Faktor internal dari diri mahasiswa itu sendiri sedangkan faktor eksternal termasuk dosen dan orang tua (Anisa et al., 2021). Orang tua juga harus mendukung mahasiswa secara moril sehingga mereka selalu memiliki rasa percaya diri. 


\section{SIMPULAN}

Berdasarkan hasil penelitian dan pembahasan, dapat disimpulkan bahwa terdapat hubungan yang positif antara higher order thinking skills dan kemampuan literasi sains mahasiswa pendidikan biologi Universitas Muhammadiyah Makassar dengan nilai korelasi sebesar 0,370. Nilai hasil belajar dengan pengkategorian rata-rata high order thinking skills sebesar 56,7 dan rata-rata kemampuan literasi sains sebesar 66,7. Mahasiswa yang memiliki high order thinking skills dan kemampuan literasi sains akan mampu melaksanakan pembelajaran dengan baik dalam kegiatan akademik yang cukup padat. Sehingga hal demikian dapat membantu mahasiswa memperoleh indeks prestasi yang cemerlang.

\section{UCAPAN TERIMA KASIH}

Penulis mengucapkan terima kasih kepada semua pihak yang telah membantu dan mendukung keterlaksanaan penelitian ini. Terkhusus kepada LP3M Universitas Muhammadiyah Makassar sebagai lembaga yang mewaliki Universitas dalam proses menyeleksi proposal dan mendanai penelitian kami ini untuk anggaran hibah internal PT 2021. Dan kepada ketua prodi pendidikan biologi serta mahasiswa pendidkan biologi Universitas Muhammadiyah Makassar yang terlibat dalam penelitian ini.

\section{RUJUKAN}

Ahmad, D. N., Setyowati, L., Pujaning, A., \& Suhendri, H. (2020). Analisis Sistem Penilaian Hots (Higher Order Thinking Skills) Dalam Mengukur Kemampuan Berpikir Kritis Dan Kreatif. BIOTIK: Jurnal IImiah Biologi Teknologi Dan Kependidikan, 8(1), 11-23. https://doi.org/10.22373/biotik.v8i1.6600

Andriani, N., Saparini, S., \& Akhsan, H. (2018). Kemampuan Literasi Sains Fisika Siswa SMP Kelas VII Di Sumatera Selatan Menggunakan Kerangka PISA (Program for International Student Assesment). Berkala IImiah Pendidikan Fisika, 6(3), 278-291. https://doi.org/10.20527/bipf.v6i3.5288

Anisa, Magfirah, N., \& Thahir, R. (2021). Peranan Self Efficacy dan Self Regulated Learning Terhadap Prestasi Akademik Mahasiswa ( The Role of Self Efficacy and Self Regulated Learning on Student Academic Achievement ). Biodik: Jurnal IImiah Pendidikan Biologi, 7(2), 63-70. https://doi.org/https://doi.org/10.22437/bio.v7i2.12824

Asyhari, A., \& Hartati, R. (2015). Profil Peningkatan Kemampuan Literasi Sains Siswa Melalui Pembelajaran Saintifik. Jurnal IImiah Pendidikan Fisika Al-Biruni, 4(2), 179-191. https://doi.org/10.24042/jpifalbiruni.v4i2.91

Bagasta, A. R., Rahmawati, D., M., D. M. F. Y., Wahyuni, I. P., \& Prayitno, B. A. (2018). Profil Kemampuan Literasi Sains Peserta Didik di Salah Satu SMA Negeri Kota Sragen. PEDAGOGIA: Jurnal Pendidikan, 7(2), 121-129. https://doi.org/10.21070/pedagogia.v6i1

Fitriani, D., Suryana, Y., \& Hamdu, G. (2018). Pengembangan Instrumen Tes Higher-Order Thinking Skill pada Pembelajaran Tematik Berbasis Outdoor Learning di Sekolah Dasar. Pedadidaktika: Jurnal IImiah Pendidikan Guru Sekolah Dasar, 5(1), 252-262. http://ejournal.upi.edu/index.php/pedadidaktika/index

Intan, F. M., Kuntarto, E., \& Alirmansyah, A. (2020). Kemampuan Siswa dalam Mengerjakan Soal HOTS (Higher Order Thinking Skills) pada Pembelajaran Matematika di Kelas V Sekolah Dasar. JPDI (Jurnal Pendidikan Dasar Indonesia), 5(1), 6-10. https://doi.org/10.26737/jpdi.v5i1.1666

Musalina, M., Tahang, L., \& Erniwati, E. (2019). Kemampuan Literasi Teknologi Siswa Kelas X pada Program Keahlian Multimedia: Analysis \& Deskripsi. Jurnal Penelitian Pendidikan Fisika, 4(1), 1-7. https://doi.org/10.36709/jipfi.v4i1.14137

Mustapa, K. (2014). Pengaruh Strategi Pembelajaran terhadap Kemampuan Berpikir Tingkat Tinggi. Jurnal Pendidikan Humaniora, 2(4), 348-357. http://journal.um.ac.id/index.php/jph

Purwanto. (2013). Prinsip-Prinsip dan Teknik Evaluasi Pengajaran. Bandung: Remaja Rosda Karya. Rahayuni, G. (2016). Hubungan Keterampilan Berpikir Kritis Dan Literasi Sains Pada Pembelajaran Ipa 
Terpadu Dengan Model PBM Dan STM. Jurnal Penelitian Dan Pembelajaran IPA, 2(2), 131-146. https://doi.org/10.30870/jppi.v2i2.926

Septiani, D. A., Junaidi, E., \& Purwoko, A. A. (2020). Hubungan Antara Keterampilan Berpikir Kritis Dan Kemampuan Literasi Sains Pada Mahasiswa Pendidikan Kimia Di Universitas Mataram. 1, 15-19. https://jurnalfkip.unram.ac.id/index.php/PSN/article/view/1579

Sugiyono. (2017). Statistika Untuk Penelitian. Bandung: Alfabeta.

Susiati, A., Miarsyah, M., \& Adisyahputra. (2018). Hubungan Kemampuan Membaca Pemahaman dan Kemampuan Berpikir Tingkat Tinggi dengan Kemampuan Literasi Sains Guru Biologi. BIOSFER: Jurnal Pendidikan Biologi (BIOSPERJPB), 11(1), 1-12. http://journal.unj.ac.id/unj/index.php/biosfer/article/download/5363/4714

Thahir, R., Magfirah, N., \& Anisa. (2021). Pengembangan Penuntun Praktikum Keanekaragaman Hewan Berbasis Contextual Teaching and Learning Mahasiswa Pendidikan Biologi. Jurnal Biotek, 9(1), 75-92. https://doi.org/http://dx.doi.org/10.24252/jb.v9i1.20936

Wibawa, R. P., \& Agustina, D. R. (2019). Peran Pendidikan Berbasis Higher Order Thinking Skills (Hots) Pada Tingkat Sekolah Menengah Pertama di Era Society 5.0 Sebagai Penentu Kemajuan Bangsa Indonesia. EQUILIBRIUM : Jurnal IImiah Ekonomi Dan Pembelajarannya, 7(2), 137-141. https://doi.org/10.25273/equilibrium.v7i2.4779

Yuliati, Y. (2017). Literasi Sains Dalam Pembelajaran Ipa. Jurnal Cakrawala Pendas, 3(2), 21-28. https://doi.org/10.31949/jcp.v3i2.592

Yuriza, P. E., Adisyahputra, \& Sigit, D. V. (2018). Hubungan antara Kemampuan Berpikir Tingkat Tinggi dan Tingkat Kecerdasan dengan Kemampuan Literasi Sains pada Siswa SMP. BIOSFER Jurnal Pendidikan Biologi, 11(1), 13-20. https://doi.org/https://doi.org/10.21009/biosferjpb.11-1.2 